\title{
高齢ドライバの運転評価に向けた運転特性データベース ${ }^{1}$ \\ Data Repository for Human Life-Driving Anatomy (Dahlia)
}

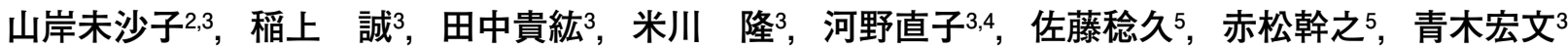

\begin{abstract}
Various data related to driving of older drivers were collected in this research to construct database, called Data Repository for Human Life-Driving Anatomy (Dahlia). The database includes visual functions, cognitive performance, driving aptitude tests, and questionnaires about driving attitudes and belief obtained from approximate 300 drivers. Further, naturalistic driving study has been conducted to collect driving behavior from some drivers. This paper describes concept of the database, details of data collection, case of the present applications, and prospects.
\end{abstract}

本研究では，高齢ドライバの運転に関するさまざまなデータを収集し，運転特性データベース，Data Repository for Human Life-Driving Anatomy（Dahlia）にまとめている. Dahliaには, 約300名のドライバが 登録し，視覚機能や認知機能，運転適性，運転に関する主観的側面といった人間特性データが含まれている. さらに, ドライバの一部からはnaturalistic driving studyの手法による長期運転行動データを収集し，まとめた. 本論文では，データベースの概要とデータ収集方法，データベースの具体例と今後の展望について述べる. (キーワード : 高齢ドライバ，データベース構築，視覚・認知機能，主钼計測，naturalistic driving data)

\section{1.はじめに}

近年の高齢ドライバが関わる交通事故の問題を背景と して，政府は運転免許証の自主返納制度の周知，公共交 通機関の確保に向けた取組み，地域運営組織による外出 支援等の地域での取組みといった対策を提案している. さらに，高齢者にとって運転が主要な移動手段であるこ とを考慮し，高齢運転者への講習等の充実，道路交通環 境の整備等事故危険箇所対策の推進, 高齢運転者の特性 を考慮した運転継続のための対策も議論している11. この

1 受付：2019年1月21日 受理：2019年11月19日

2 愛知淑徳大学

Aichi Shukutoku University

3 名古屋大学未来社会創造機構

Institutes of Innovation for Future Society, Nagoya University

4 名古屋大学大学院医学系研究科精神医学分野

Department of Psychiatry, Nagoya University Graduate School of Medicine

5 (国研) 産業技術総合研究所自動車ヒューマンファクター研究セン ター

Automotive Human Factors Research Center, National Institute of Advanced Industrial Science and Technology
ような取組みや対策の進展には，高齢ドライバの理解が 重要となる。そこで本研究では，運転継続の判断に役立 つ運転能力評価法や自動車の支援システムの研究開発に 活用できる高齢者運転特性データベースの構築を試みた.

本研究は, 名古屋大学COI (Center of Innovation)2) の 一環として実施された。名古屋大学COIは，「人がつなが る “移動”イノベーション拠点〜高齢者が元気になるモ ビリティ社会〜」を主題として，文部科学省の「革新的 イノベーション創出プログラム (COI STREAM)」に採 択され，2013年から9年間の計画で研究・開発を行って いる．プロジェクトは，モビリティ研究，情報基盤研究 など異なる領域で構成され，本研究はモビリティ研究の 人間・加歯特性研究部門に属し，ドライビングシミュレー タによる実験室実験や支援機器開発，データベース構築 等を進めている. 本稿で取り上げるデータベース構築は， 一般高齢ドライバの視覚・認知機能，運転行動等のデー タを運転特性データベースとしてまとめる試みであり, 高齢ドライバの安心・安全なモビリティライフを考案す る学際的な研究開発への活用を企図している.

2013年度にデータベース構成を計画し，2014年度か ら名古屋地区，2015年度からはつくば地区でもデータ収 
集を始めた。さらにドライバの同意が得られた場合には， 毎年データを収集し，縦断的データを構築する計画であ る．このデータ収集は，新規リクルートと追跡調査とを 併せた 50 歳以上のドライバ年間 300 名を目標とし, 名古 屋大学COIの継続期間中可能な限り毎年この水準を維持 する予定である. 本研究では，このデータベースをData Repository for Human Life-Driving Anatomy : Dahlia (ダ リア）と呼ぶ.

\section{2. 高齢ドライバ運転データベースの動向}

高齢ドライバを含む運転特性データベースは，国外で は国の支援を受けた大規模な研究プロジェクトによって 支えられている．たとえば，運転行動調査を中心とし たThe 100-car naturalistic driving study ${ }^{3)}$ や高齢ドライバ の運転の安全性評価方法を確立することを目的とした Candrive II / Ozcandrive ${ }^{4)}$, 主に事故の背景要因の解明を 目指すSHRP2 $2^{5)}$ がある。これらのデータベースは，それ ぞれ100名から約1000名以上の規模であり，現在でもさ まざまな研究で活用されている。しかし，データを使用 する上では，文化や社会的慣習，法令等必ずしも自国の 状況に置き換えられないことや，他国のデータベースへ のアクセスが困難であることが課題として指摘される ${ }^{6)}$. そのため，オーストラリアでは，Transport and Road Safety（the University of New South Wales）を中心とした The Australian 400-car naturalistic driving study ${ }^{6)}$ 発足 し，自国のデータベースを構築している.

日本の高齢ドライバ運転特性データの代表例には高齢 者講習のデータが挙げられるが，これは受講時の認知機 能低下や運転能力を確認するために実施されるものであ り，体系化されたデータは公開されていない，現在公開 されている運転特性データベースには，人間生活工学研 究センター(Research Institute of Human Engineering for Quality Life：HQL）の高齢者を含む運転行動データベー ス778)がある.これは，多くのセンサを搭載した車両によ る公道での詳細な運転行動と運転に関する意識等のアン ケートを組み合わせた日本初の 100 名規模のデータベー スである，走行環境が統制されているため，特定場面で の運転行動を解析することができ，場面ごとの運転行動 モデルの構築，支援技術の探索や開発に活用されている. しかしながら，通常運転のデータを得ることを目的にし ており，データ取得期間は2ヶ月程度であることから事 故等の危険事象のデータは限られている。また，人間生 活工学研究センターデータベースサイトの高齢者身体機 能データベース9) や産業技術総合研究所の高齢者・障害
者の感覚特性データベース ${ }^{10)}$ は大量の人間特性データを まとめているが，運転には関連していない。これらのこ とを考慮すると, Dahliaは高齢ドライバに重点を置き， 豊富な人間特性データと長期にわたる運転行動データを 併せ持つ特異なデータベースといえよう。

\section{Dahliaの概要}

Dahliaは人間特性データと運転行動データで構成され ており，全員がまず人間特性データの収集に参加し，そ のデータに基づいて選抜されたドライバが運転行動デー タの対象となったテデータ収集に際しては，事前に名古 屋大学未来社会創造機構倫理審査委員会の承認を受け, 参加ドライバにはデータ収集開始前に口頭かつ書面で研 究について説明し，書類への署名にて参加への同意を得 た。一部の参加者からは追跡調查への同意も得られ，中 高年期から前期高齢期，前期高齢期から後期高齢期への 変化といった縦断的な観測が可能となった。この縦断的 データ収集の過程で運転免許証の返納または運転頻度の 減少が認められた場合には，運転制限・運転断念への過 程を記録した貴重な資料といえる，図1はDahliaの全体構 成2)であり，このデータを年々更新することにより，特 定の指標で層別されたドライバタイプの変動が得られる. 表1は，2014年度登録ドライバを例として，ベースライ ン計測（BL）と1年後計測（1Y）の名古屋地区，つくば 地区それぞれの推移を示した（1Yの人数は1年で年齢区 分を移動しているために数が増減)。さらに，年間 300 名 のデータ収集を維持するために，現在まで毎年ドライバ を増補している，例えば，表1の1Yのタイミングでは，

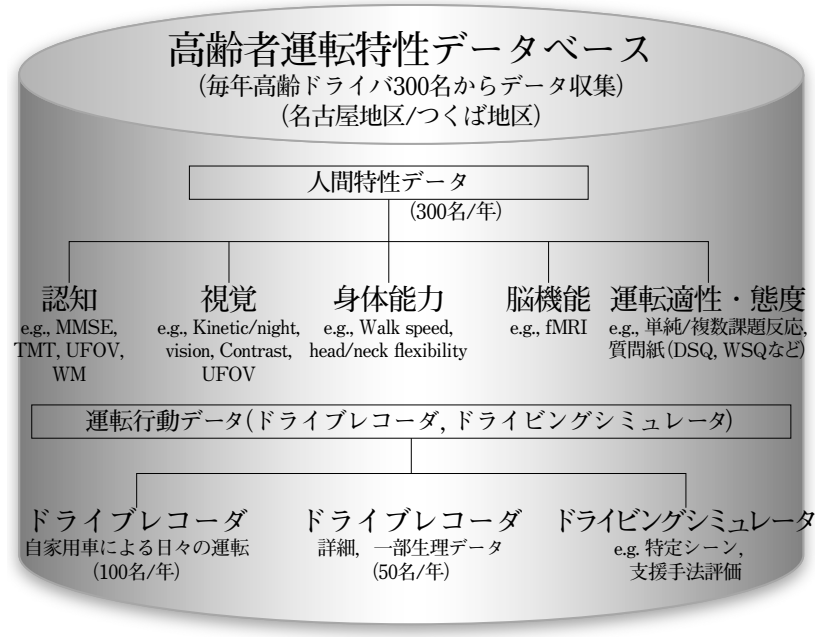

図1 Dahliaの全体構成

Fig. 1 Outline of the Dahlia. 
表1 Dahlia初期のBLから1Yのドライバ数の推移

Tab. 1 The number of drivers between BL and $1 Y$ enrolled in the Dahlia from the first period.

\begin{tabular}{llrrrrrr}
\hline & & \multicolumn{2}{c}{ 名古屋 } & \multicolumn{2}{c}{ つくば } & \multicolumn{2}{c}{ 全体 } \\
& & BL & $1 Y$ & BL & $1 Y$ & BL & $1 Y$ \\
\hline 男性 & $20 \sim 49$ 歳 & 17 & 0 & 29 & 0 & 46 & 0 \\
& $50 \sim 64$ 歳 & 17 & 12 & 19 & 11 & 36 & 23 \\
& $65 \sim 74$ 歳 & 61 & 48 & 28 & 23 & 89 & 71 \\
& 75 歳以上 & 31 & 26 & 7 & 10 & 38 & 36 \\
\hline 女性 & $20 \sim 49$ 歳 & 9 & 0 & 31 & 0 & 40 & 0 \\
& $50 \sim 64$ 歳 & 30 & 23 & 24 & 15 & 54 & 38 \\
& $65 \sim 74$ 歳 & 62 & 47 & 18 & 13 & 80 & 60 \\
& 75 歳以上 & 25 & 18 & 4 & 3 & 29 & 21 \\
\hline 全体 & $20 \sim 49$ 歳 & 26 & 0 & 60 & 0 & 86 & 0 \\
& $50 \sim 64$ 歳 & 47 & 35 & 43 & 26 & 90 & 61 \\
& $65 \sim 74$ 歳 & 123 & 95 & 46 & 36 & 169 & 131 \\
& 75 歳以上 & 56 & 44 & 11 & 13 & 67 & 57 \\
\hline 合計 & & 252 & 174 & 160 & 75 & 412 & 249 \\
\hline
\end{tabular}

追跡調査249名に対して，両地区併せて82名（50歳以上） をBLとして追加した。

\section{3-1. データベース計測項目}

計測項目は，運転評価や適正検査，運転行動予測の研 究11 13) から, 視覚機能検査, 認知機能検査, 反応時間測 定，運転に関する主観評価を選定した。

視覚機能 : 高齢者講習に含まれる静止視力 (SVA) と動 体視力 (KVA) (AS-4F動体視力計, 興和創薬株式会社 製), 夜間視力 (NV) (AS-14B夜間視力計，興和創薬株 式会社製)，水平視野 (HVF) を計測した。コントラス 卜感度検査は, 高齢者講習には含まれないが，運転成績 や交通事故，運転制限や運転断念 ${ }^{14,15)}$ と関連すると考え られるため, The Driving Health Inventory ${ }^{\circledR}(\mathrm{DHI})^{16)}$ に含 まれる簡略的な文字コントラスト感度検査と，標準的な 縞コントラスト感度検査 (CSV-1000, Vector Vision TM 製)により計測した. 後者の検査器には, 両端に自動車 のヘッドライトを模擬したライトがあり，これを点灯し たグレアあり条件によって高輝度光への曝露を考慮した コントラスト感度も測定した. これら視覚機能計測時には， 普段運転時に眼鏡等を使用しているドライバはそれらを 装着した状態で測定した。

認知機能：運転には記憶や注意，実行機能など多様な 認知機能が関わるため, 多くの運転評価では複数の検 査や課題を組み合わせている. The Mini-Mental State Examination (MMSE) やTrail-making test (TMT) は, 運 転評価でも使われる神経心理学的検査である. MMSEは, 非器質的な認知機能低下と器質的な機能低下を識別する スクリーニング検査として開発され，認知症の診断にも
利用される ${ }^{17)}$. TMTは，視覚探索，注意，運動速度，注 意の切り替え，実行機能を反映し，高齢ドライバの運転 能力低下のスクリーニング18) や運転スキルの予測因子に なると言われている12)．DHIにもTMTと同じ手続きのVS A，VS Bがある。しかし，これはPCで制御され，文字 刺激をアルファベットとすることから，高齢者のPC使 用経験や日本人のアルファベットへの親和性が成績に影 響する可能性がある。そこでDahliaでは，紙上で実施す るひらがなのTMTも実施した.

有効視野検查 (the Useful Field of View test : UFOV) も運転を安全に遂行するための認知的，視覚的機能を評 価する検查であり，転倒や運転能力の視覚的問題や事 故リスクの予測因子であると言われている ${ }^{19,20)}$. UFOV は正答率を指標とする場合もあるが，DHIのUFOVでは 情報処理速度（ターゲット刺激提示時間）を指標として いる.

$\mathrm{DHI}^{16)}$ は，上記に加えて，迷路課題（MAZE）や遅延 再生課題, 補完課題 (VMI) など 8 種類の認知課題を含む テストバッテリであり，運転能力をスクリーニングする ツールとしてアメリカで開発された。 ここには，下肢の 運動機能と体のバランスをみるWalk，座位での頸部動作 性を測定するhead/neck flexibility課題も組み込まれ，認 知機能と身体機能を同時に評価することができる.

さらに，基礎的な認知機能の評価として，産総研式認 知的加齢特性検查（AIST-CAT）も実施した。これは, 認知的に健康な高齢者の認知機能変化を評価するために 開発され，視覚的注意やワーキングメモリ，プランニング, タスクスイッチの各機能を評価する検査である ${ }^{21)}$.

反応時間 : 運転時の衝突回避等, 反応時間は運転にとっ て重要な指標である ${ }^{12)}$ 。現在の高齢者講習では運転適 性検査器による反応時間測定は実施されていないが, Dahliaではかつて高齢者講習で使われていた装置と同種 の装置を用いて単純・選択反応時間等複数の反応時間を 計測している。これらは，運転に関わるドライバの精神 過程を反映すると考えられている22).

運転に関する態度・意識：心身の状態や認知機能・感 覚機能の低下に関する広範囲の信念（belief）も運転行

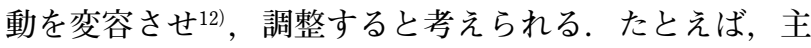
観評価による感覚器官の変化や健康状態，運転スキル に対する気づきは補償的な行動や運転の自己制限（selfregulation）に影響し ${ }^{23)}$ ，補償的方略の種類や数は運転成 績および交通事故歴によって変わる ${ }^{24)}$ など，意識や態度 は運転行動に重要な役割を果たすと言われている。そこ でDahliaでは，主観評価として1）自動車運転に対する意 識のアンケート，2) 運転の変化に関するアンケートと3) 
表2 Dahliaにおける人間特性データの概要

Tab. 2 Outline of the human characteristics data in the Dahlia.

\begin{tabular}{|c|c|}
\hline 機能 & 計測内容 \\
\hline \multirow{5}{*}{ 視覚機能 } & 静止視力（static visual acuity, SVA） \\
\hline & 動体視力（kinetic visual acuity, KVA） \\
\hline & 夜間視力（night vision, NV） \\
\hline & コントラスト感度検査（グレアなし・あり） \\
\hline & 水平視野（horizontal visual field, HVF） \\
\hline \multirow{16}{*}{ 認知機能 } & MMSE \\
\hline & TMT Part A and B \\
\hline & 産総研式認知的加齢特性検査 (AIST-CAT) \\
\hline & DHI \\
\hline & High- and low-contrast visual acuity \\
\hline & Leg strength and stamina \\
\hline & Head/neck flexibility \\
\hline & Route planning (MAZE1, MAZE2) \\
\hline & Short-term and working memory (Memory) \\
\hline & Visualization of missing information (VMI) \\
\hline & Visual search with divided attention (VS A, VS B) \\
\hline & Visual information processing speed (UFOV) \\
\hline & 運転適性検査器（7検査） \\
\hline & 単純反応時間検査，選択反応時間検査（5検査） \\
\hline & 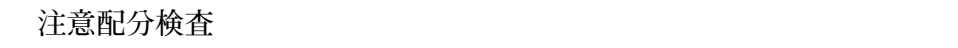 \\
\hline & ハンドル操作検査 \\
\hline \multirow{5}{*}{$\begin{array}{l}\text { 運転に関する態度・意識 } \\
\text { (ドライバの属性, 主観評価) }\end{array}$} & 1）自動車運転に対する意識のアンケート（運転習慣など） \\
\hline & 2) 運転の変化に関するアンケート \\
\hline & 3）対処行動アンケート \\
\hline & 4）負担感受性チェックシート (Workload sensitivity questionnaire: WSQ) \\
\hline & 5）運転スタイルチェックシート（Driving style questionnaire: DSQ） \\
\hline ドライバ情報と健康状態 & $\begin{array}{l}\text { 年齢，性別，教育歴，車種 } \\
\text { 健康状態（睡眠時間，血圧，既往歴，眼疾患の有無，服薬状況） }\end{array}$ \\
\hline
\end{tabular}

対処行動アンケート ${ }^{25)}$ ，4）負担感受性チェックシート (Workload sensitivity questionnaire : WSQ) と5) 運転スタ イルチェックシート (Driving style questionnaire : DSQ) ${ }^{26)}$ の5種類の質問紙を使用した。

健康状態：健康状態も運転に影響し，たとえば関節炎や パーキンソン病, 脳卒中よりも, 視覚機能低下が運転制 限や断念の要因になることが示されている15)。これは, 白内障や緑内障, 糖尿病網膜症, 加齢黄斑変性などの眼 疾患が運転の困難さや運転制限に関連する27) ことと一 致する。 また，疾病に伴う薬物使用は状態を改善する一 方，安全運転を損なう可能性があるなど薬物ごとの運転 への影響も議論されている ${ }^{28)}$ 。これらを考慮し, Dahlia では疾病および眼疾患の既往歴，服薬の情報も収集した。 表2にDahliaの人間特性データの概要を示す.

\section{3-2. 運転行動データの概要}

対象ドライバと取得データの概要：Dahliaに登録してい るドライバのBLの人間特性データの年齢や性別を考慮
して候補者を選抜し，同意が得られたドライバの自家用 車にドライブレコーダ（DR）を設置した。このとき，自 動車の利用頻度や走行環境（運転コースや時間帯等）に 関する統制は行わず，普段通りの運転を求めた．名古 屋地区では50〜83歳までの62名に対して2015年2月から データ収集を開始した。つくば地区では52〜78歳までの 35名を対象に2016年11月からデータ収集を開始し，両地 区の収集は現在（2019年1月時点）も継続している。名 古屋大学COIの終了を区切りとしているが，この間にド ライバから中断の申し出があった場合にはDRを取り外 し，それ以降のデータ収集を中止した。

使用したDRは，BU-DRHD421 (Yupiteru社製) で，10 〜 15 fpsで録画された前方カメラによる前景映像，加速 度センサによる三軸の加速度，GPSによる位置情報お よび速度が記録された，常時録画モードでは，エンジン 始動時のアクセサリー (ACC) オンからオフまでの映像, 加速度，GPSデータが記録（全録り）された. イベント 記録モードでは，急な加速度変化や車両への衝撃をトリ 
ガとして，その前後10秒間の映像，加速度，GPSデータ が記録された。履歴記録モードは，ACCオンからオフま での日時や加速度，GPSのテキストデータが記録された。 取得データの活用 : 現在はイベント記録と履歴記録に基 づいてデータを整理している，イベント記録では，一定 の加速度変化が生じた場面が自動的に記録されるが，中 には道路の凹凸やドア開閉のような運転に起因しない事 例も含まれる。そのため，2名の判定者がそれらの事例

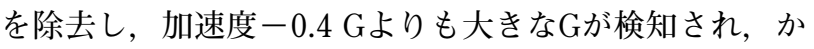
つその加速度が走行中および交差点での対象物（他車 両や歩行者, 工作物, 信号) との接近を避けるための操 作あるいはこれらとの接触・衝突があったかどうかを基 準として事例の選別，特徴の記述，分類を行った。選 別の精度を高めるために，判定者とは別の最終判定者 が各事例の記述内容や分類を決定した。これらの事例 は，ヒヤリハット，ニアミスと言われることが多いが， ISOの技術文書（ISO TR21974-1） ${ }^{29)}$ に倣ってニアクラッ シュ (Near-crash) と呼ぶ.このニアクラッシュは, 衝突 (conflict) の可能性を回避するための緊急回避行動が必要 とされた状況と定義されている。ここではCrash事例と 併せてCrash and Near-crash (CNC) としてカウントする.

履歴記録からは，自動車を使用した頻度や運転継続時 間，走行距離を算出した。このような運転習慣は質問紙 で収集されることが多いが，主観的な運転習慣と客観的 な運転習慣との不一致も報告 ${ }^{30)}$ されているため, DRに よる運転記録は実態把握において重要である。特に日本 の高齢ドライバにおける客観的な運転習慣データは前例 が少ないため, 本研究の長期運転行動データは高齢ドラ イバの自動車利用状況を確認する貴重な情報といえよう.

\section{Dahliaの具体例}

Dahliaの50歳以上の人間特性（BLのデータ）および運 転行動データの具体例を図2～図6に示す．名古屋地区と つくば地区の 214 名のBLデータに基づいて，罒 2 視覚 機能のうちのコントラスト感度を取り上げ，年齢に対し てプロットした。罒2から，グレアあり条件のコントラ スト感度の方がグレアなし条件よりも低く $(t(213)=6.94$, $p<.01)$ ，加齢によって低下する傾向がみられた。認知 機能に扣いては，BLのMMSEとTMTの成績を年齢に対 してプロットした（図3). 図3から，TMT part Bの遂行 時間の分散が大きく $(F(176,176)=0.08, p<.01)$, 加 齢による個人差の拡大が示唆された。また，図4はBLの 年歯群別のAIST-CATの標準化得点である．作業記憶と プランニングは64歳以下と65歳以上との間で差があるこ

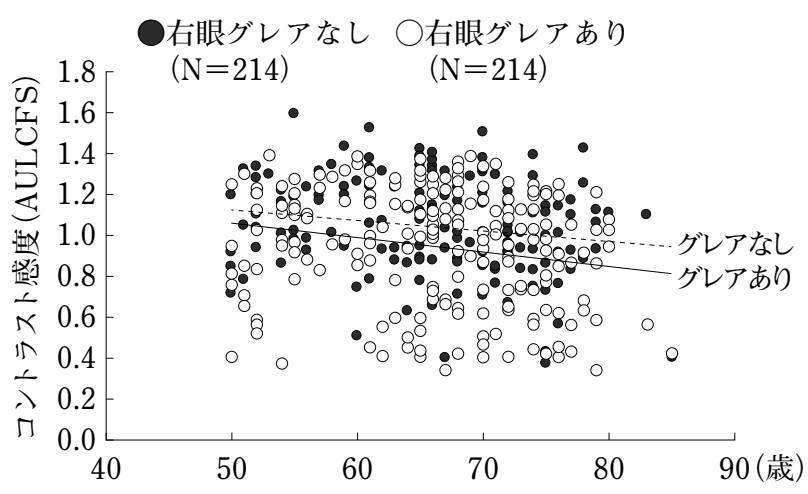

図2 BLのコントラスト感度の分布

Fig. 2 Distribution of contrast sensitivity at BL. *AULCFS: Area under log contrast sensitivity function.

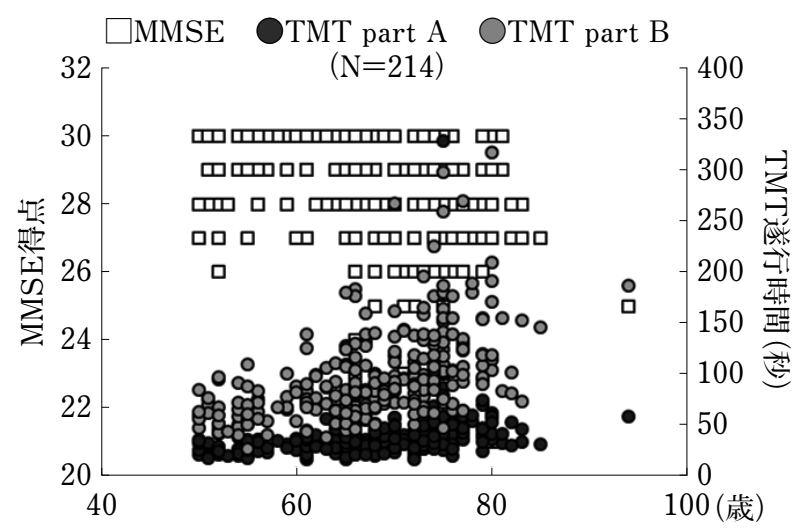

図3 BLの年齢とMMSE，TMTの成績

Fig. 3 Age and performances of MMSE and TMT at BL.

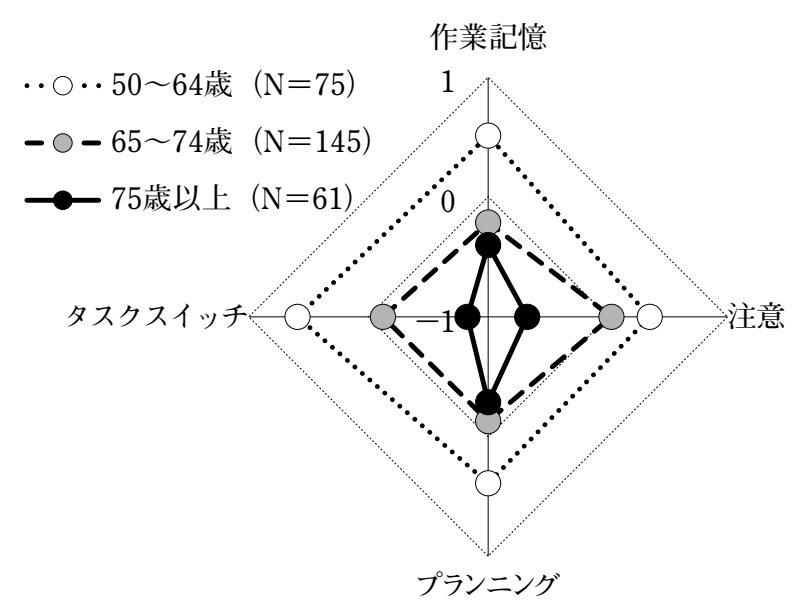

図4 BLの年齢群別のAIST-CAT標準化得点

Fig. $4 \mathrm{Z}$ scores of AIST-CAT for three age groups of BL.

とが示されたが $(F(2,211)=16.48, p<.01 ; F(2,211)$ $=33.20, p<.01)$ ，注意とタスクスイッチは年齢によっ て段階的に変化している $(F(2,211)=14.20, p<.01 ; F$ $(2,211)=33.20, p<.01)$. BLで取得した主観評価のう ち対処行動アンケートの各因子の平均得点を地域別に算 


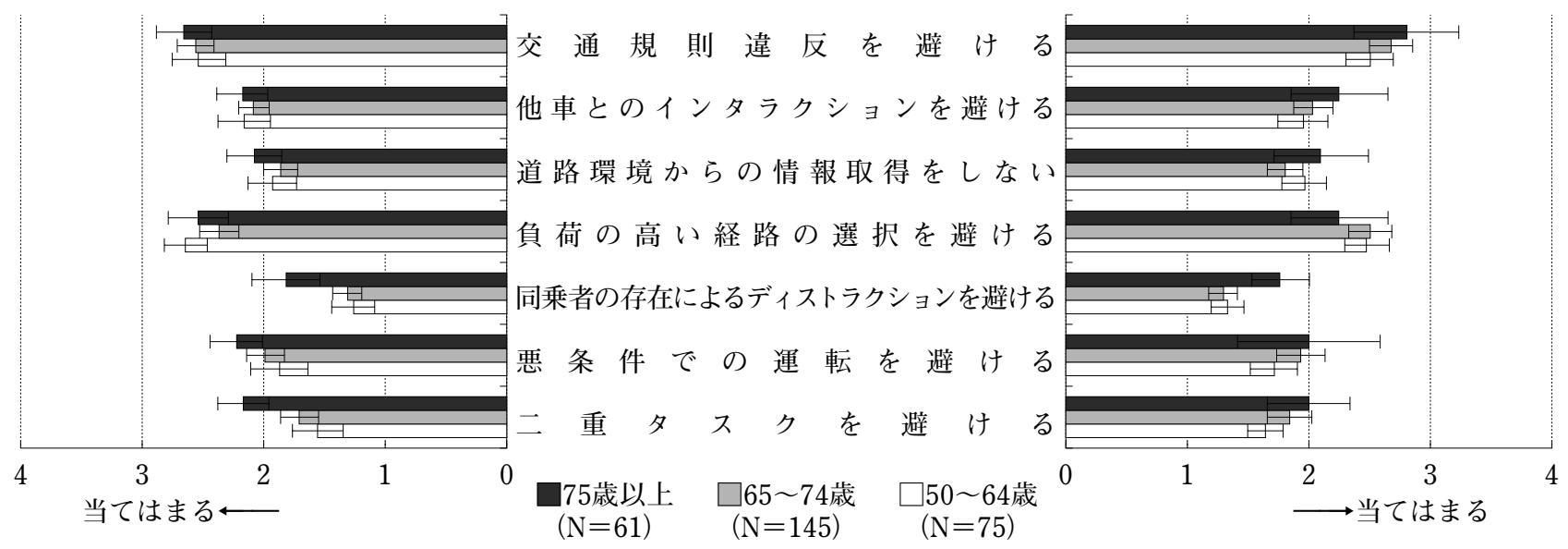

図5 BLの年齢群抢よび地域別の対処行動アンケート

Fig. 5 Scores of the compensatory strategies for age group and drivers' residence at BL.

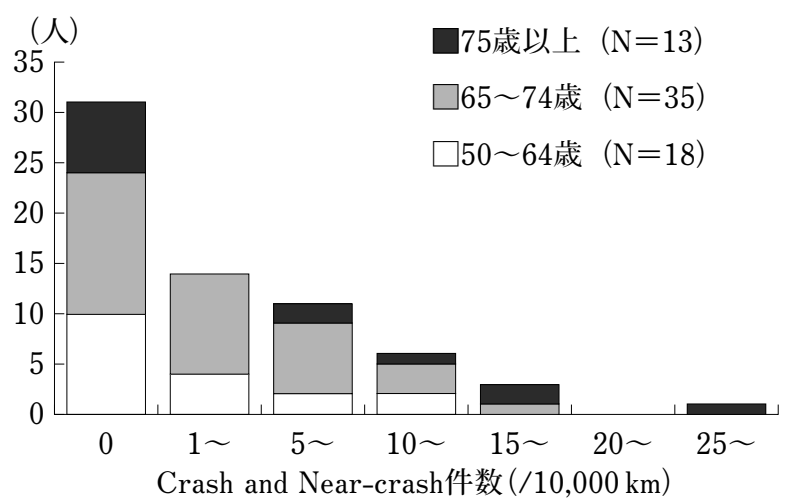

図6 年齢群ごとのCNC件数の分布 (名古屋地区のドライバ 62名より)

Fig. 6 Distribution of CNC events for three age groups $(62$ drivers of Nagoya area).

出した (図5)。「悪条件での運転を避ける」と「二重タ スクを避ける」は，75歳以上の得点が高く $(F(2,207)=$ $4.77, p<.01 ; F(2,205)=9.86, p<.01)$, 有意ではない が, 名古屋地区の得点がやや高い傾向がみられる. 図6は, DRを装着した名古屋地区の62名を対象に10,000 kmあた りのCNC件数を年齢群ごとに積み上げた図である。各階 級の年齢群による偏りはみられず $\left(\chi^{2}(10)=13.61, n . s.\right)$, 全体的に本研究のドライバの約半数 $(47 \%)$ はCNCが 0件であった． 3 群は，50 64歳が 18名，65〜 74歳が 35名，75歳以上が13名と母数が異なるため議論の余地は あるが，母数の少ない75歳以上で件数が多いことから， 年齢によって分布の幅が広くなることが示唆される.

項目間の関係性に関して, 詳細は以下の文献に譲るが, たとえば100名のBLデータから高齢ドライバの視覚機能, 認知機能，運転適性検査の特徵をまとめ，年齢によって 差がある能力としてDHIのMAZEやUFOV，運転適性検
査の注意配分といった注意機能や実行機能成績，年齢に よる差が認められない能力としてDHIのVMIが示されて いる ${ }^{31}$ 。 このような運転に関わる機能的側面（表2の視 覚機能や認知機能）に加えて，運転に関する意識や態度 といった主観評価との関係性を検討したSato et al. ${ }^{25)}$ は, 認知機能成績としてAIST-CATを，主観評価として3-1 で挙げた質問紙2)〜5）を用いて，両者の関係をべイジ アンネットワークによってモデル化した．認知機能は運 転の変化の気づきに影響し，対処行動を決定すると考え られるため，認知機能は運転の変化と対処行動の双方に 関連すると予測したが，モデルから認知機能は対処行動 に直接的に影響する一方，運転に関する変化にはほとん ど関連しないことが示された。ささらに，佐藤らは高齢ド ライバの縦断的変化にも着目している ${ }^{21)}$. BLと $1 Y$ を比 較して，1Yに特定の機能が向上する，あるいは特定の機 能が低下する7つのカテゴリ（1：1Y注意向上，2：1Yプ ランニング向上， $3: 1 \mathrm{Y}$ 作業記憶低下，4：1Y作業記憶 とタスクスイッチ向上，5：1Yプランニング低下とタス クスイッチ向上， $6: 1 Y$ 変化なし，7：1Y注意機能低下) にドライバが分けられることを示した。この結果は，機 能変化のプロセスの違いによる個別の運転能力評価・支 援の重要性を示唆している.

運転行動データについては，高齢ドライバの運転習慣 やCNCに着目している。たとえば，166件のCNCを目的 変数，認知・視覚機能，主観評価といった人間特性を説 明変数，走行距離をオフセット項としたポアソン回帰分 析により，CNCに関わる要因を探索した。この分析から MMSE等7つの人間特性変数を投入したCNCの推定モデ ルが得られ，人間特性の水準別のCNCの発生件数の推定 から安全性評価への応用可能性が示された ${ }^{32}$. 


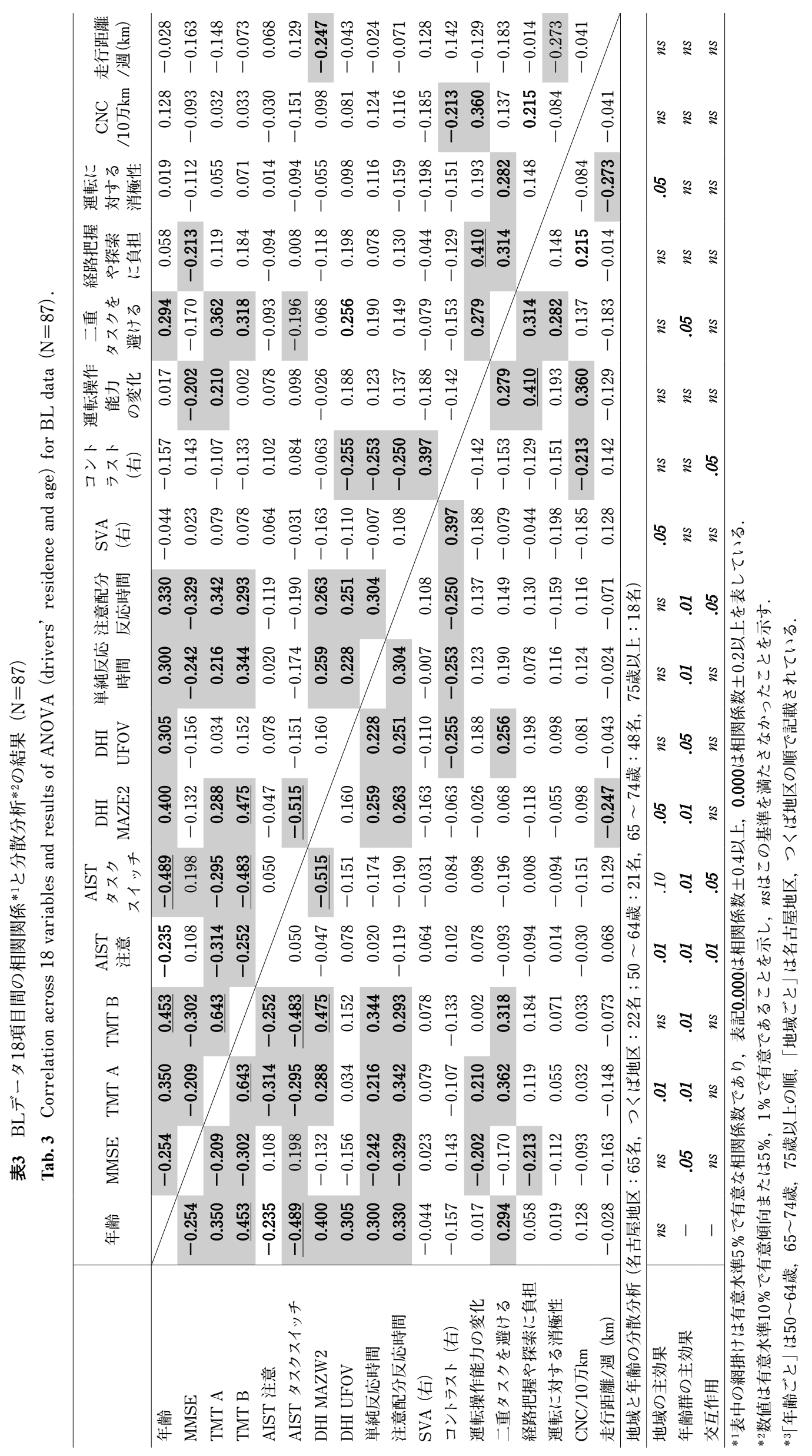


全体のデータを俯瞰するために，名古屋地区とつく ば地区の87名のBLのデータを用いた項目間の相関関係 と, 各項目の地域（名古屋地区，つくば地区）と年齢群 (50〜64歳，65〜 74歳，75歳以上）の違いによる分散分 析の結果の一部を表3に示す. 表3から, 認知機能検査間 の関係と, 認知機能と「運転操作能力の変化」や「二重 タスクを避ける」といった主観評価との関連性が示され た. コントラスト感度と反応時間との間には弱い相関関 係があるが，SVAにはそれがみられないことから，同じ 視覚機能でも性質が異なる可能性が示唆された。 CNCに ついては，CNCの少ないドライバの方がコントラスト感 度は高く, 自身の変化や運転時の負担に敏感な傾向が得 られた．走行距離に関しては，走行距離の長いドライバ のMAZE成績が高く，運転への消極性が低いことが示唆 された. 分散分析の結果から, 認知機能成績には年齢に よる差が示唆されたが, 視覚機能には有意差がみられず, 眼鏡等の補正によって加齢の影響が減じられた可能性が ある，地域差については，差がみられた項目は少ないが， これは居住地名のみで大別し, 名古屋地区の多梯性が考 慮されていないためであると考えられる.

\section{5. 今後の展望}

Dahliaは, 名古屋大学COI終了まで維持される予定で あり, 将来日本の代表的なドライバ運転特性データベー スになることが期待される．現在，データはプロジェク 卜内で公開・共有しているが，産学連携や関連研究機関 との共同研究も積極的に進めており, 高齢ドライバの特 徵の解析といった基礎的研究だけでなく, 自動運転の効 果測定やシステム開発といった応用研究にも活用の幅を 拡大している，広範囲の利活用を実現するために，個人 情報やプライバシーの保護等倫理的配慮, 利用規約や長 期的な管理・運用体制などを整備しているが，高齢ドラ イバが関わる交通事故低減は重要な課題であり, Dahlia は貴重な資源になるだろう。

\section{Dahlia問合せ先}

一般社団法人 モビリティと人のデータラボ

http://mohitolab.org/

\section{謝 辞}

本研究は, 科学技術振興機構による The Center of Innovation（COI）Programの支援を受けて行われました. また，データベースの項目選定に際して支援を受けた豊 田中央研究所倉橋哲郎氏, データ収集に尽力した関係各
位に謝意を表します。

\section{参考文献}

1）内閣府. 平成 29 年版交通安全白書, 2017.

2）青木宏文, 金森等, 他. “運転寿命延伸を目指したドライバ 運転特性研究 (1) 一高齢ドライバの人間・加齢・運転特性 データベースの構築—”. 2015年春季大会学術講演会講演予 稿集. 横浜市, 2015-05-20/22, 自動車技術会, 1091-1094.

3) Dingus, T.A.; Klauer, S.G.; et al. The 100-Car Naturalistic Driving Study, Phase II - Results of the 100-Car Field Experiment. DOT HS 810 593. 2006.

4) Marshall, S.C.; Man-Son-Hing, M.; et al. Protocol for Candrive II/Ozcandrive, a multicentre prospective older driver cohort study. Accident Analysis and Prevention. 2013, 61, 245-252, doi: 10.17226/22621.

5) Hallmark, S.; McGehee, D.; et al. Initial Analyses from the SHRP 2 Naturalistic Driving Study: Addressing Driver Performance and Behavior in Traffic Safety. SHRP 2 Safety Project S08. 2013, doi: 10.17226/22621.

6) Regan, M.A.; Williamson, A.M.; et al. "The Australian 400-car Naturalistic Driving Study: Innovation in road safety research and policy”. Australian Capital Territory: Australasian College of Road Safety: Proceedings of the 2013 Australasian Road Safety Research, Policing \& Education Conference. Brisbane, Australia, 2013-0828/30, 1-13.

7）赤松幹之. 運転行動データベースの構築とアクティブ セーフティ技術への利用. 自動車技術. 2003, 57 (12), 34-39.

8）佐藤稔久，高橋昭彦. 運転行動データベースを活用した 運転行動モデリング. 自動車技術. 2014, 68 (3), 50-54.

9）人間生活工学研究センター, “HQLデータベースサイト”. https://www.hql.jp/database/, (参照2018-12-11).

10）伊藤納奈，佐川賢，他. AIST高齢者・障害者感覚特性 データベースーアクセシブルデザイン国際規格のための 人間特性データー. 人間工学. $2018,54(2), 49-55$.

11）自動車技術会中部支部. 高齢者運転適性ハンドブック： 高齢者にやさしい車社会を目指して：高齢者運転適性研 究委員会報告書. 自動車技術会. 2005 .

12) Anstey, K.J.; Wood, J.; et al. Cognitive, sensory and physical factors enabling driving safety in older adults. Clinical Psychology Review. 2005, 25 (1), 45-65, doi: 10.1016/j.cpr.2004.07.008.

13) Wood, J.M.; Horswill, M.S.; et al. Evaluation of screening tests for predicting older driver performance and safety assessed by an on-road test. Accident Analysis \& Prevention. 2013, 50, 1161-1168, doi: 10.1016/j.aap. 2012.09.009.

14) McGwin Jr, G.; Chapman, V.; et al. Visual risk factors for driving difficulty among older drivers. Accident Analysis \& Prevention. 2000, 32 (6), 735-744, doi: 10.1016/ S0001-4575 (99) 00123-2.

15) Keay, L.; Munoz, B.; et al. Visual and cognitive deficits predict stopping or restricting driving: the Salisbury Eye Evaluation Driving Study (SEEDS). Investigative Ophthalmology \& Visual Science. 2009, 50 (1), 107-113, 
doi: $10.1167 /$ iovs.08-2367.

16) TransAnalytics Health \& Safety Services, "DrivingHealth. com”. http://drivinghealth.com/, (参照 2018-9-20).

17) Woodford, H.J.; George, J. Cognitive assessment in the elderly: a review of clinical methods. An International Journal of Medicine. 2007, 100 (8) , 469-484, doi: 10.1093/ qjmed/hcm051.

18) Papandonatos, G.D.; Ott, B.R.; et al. The clinical utility of the trail making tests as predictors of driving performance in older adults. Journal of American Geriatrics Society. 2015, 63 (11) , 2358-2364, doi: 10.1111/jgs.13776.

19) Edwards, J.D.; Ross, L.A.; et al. The useful field of view test: Normative data for older adults. Archives of Clinical Neuropsychology. 2006, 21 (4), 275-286, doi: 10.1016/j.acn.2006.03.001.

20) Sakai H.; Uchiyama Y.; et al. Is the useful field of view a good predictor of at-fault crash risk in elderly Japanese drivers? Geriatrics Gerontology International. 2015, 15 (5), 659-665, doi: 10.1111/ggi.12328.

21）佐藤稔久, 赤松幹之, 他. “高齢ドライバの視覚運動協応機 能と認知機能の 2 年間比較一運転寿命延伸を目指したドラ イバ運転特性研究 $(11)$-”. 2017年春季大会学術講演会講演 予稿集, 横浜市, 2017-05-24/26, 自動車技術会, 2698-2703.

22）鶴谷和子, 貝沼義之, 他. 警察庁方式CRT運転適性検査 の開発. 科学警察研究所報告. 1990 , 交通編第 31 巻, 1 号抜 刷, 57-65.

23) Molnar, L.J.; Eby, D.W.; et al. Increasing selfawareness among older drivers: the role of self-screening. Journal of Safety Research. 2010, 41 (4), 367-373, doi: 10.1016/j.jsr.2010.06.003.

24) De Raedt, R.; Ponjaert-Kristoffersen, I. Can strategic and tactical compensation reduce crash risk in older drivers? Age and Ageing. 2000, 29, 517-521, doi: 10.1093/ageing/29.6.517.

25) Sato, T.; Akamatsu, M.; et al. "Relations between elderly drivers cognitive functions and their compensatory driving behaviors". Humanist. Proceedings of Loughborough 2016 conference. Loughborough, UK, 2016-06-30/07-01.

26) Sato, T.; Akamatsu, M. Development of an interference system for drivers' driving style and workload sensitivity from their demographic characteristics. Advances in human aspects of transportation: Part III. Stanton, A. N.; Landry, S.; et al. (Eds.), AHFE Conference, 2014, 199-210.

27) Ball, K.; Owsley, C.; et al. Driving avoidance and functional impairment in older drivers. Accident Analysis \& Prevention. 1998, 30 (3), 313-322, doi: 10.1016/S0001-4575 (97) 00102-4.

28) Hetland, A.; Carr, D.B. Medications and impaired driving: A review of the literature. Annals of Pharmacotherapy. 2014, 48 (4) , 494-506, doi: 10.1177/1060028014520882.

29) ISO TR21974-1: 2018 Naturalistic Driving Studies -Vocabulary - Part 1: Safety Critical Events.

30) Molnar, L.J.; Charlton, J.L.; et al. Self-regulation of driving by older adults: Comparison of self-report and objective driving data. Transportation Research Part F.
2013, 20, 29-38, doi: 10.1016/j.trf.2013.05.001.

31) Yamagishi, M.; Aoki, H.; et al. "Human factors and driving assessment of 100 senior drivers for delaying driving cessation”. ERTICO-ITS EUROPE, Proceedings of 22nd ITS World Congress. Bordeaux, French, 2015-10-05/09.

32) Yamagishi, M.; Yonekawa, T.; et al. "Identifying Factors Related to the Estimation of Near-Crash Events of Elderly Drivers". International Ergonomics Association, Proceedings of the 20th Congress of the International Ergonomics Association, Florence, Italy, 2018-08-26/30, 23-31.

\section{著者情報}

山岸未沙子（やまぎしみさこ，正会員，連絡著者） 2009年日本福祉大学大学院情報・経営開発研究科修了. 博士 (人間環境情報)。金沢大学感動デザイン工学研究所特別研究 員，国立研究開発法人国立長寿医療研究センター，名古屋大 学未来社会創造機構を経て，2017年より愛知淑徳大学情報教 育センター助教. 専門領域 : 加齢工学, 加齢心理学. 日本人 間工学会, 日本認知心理学会, 日本色彩学会, 日本認知症学 会, 各会員.

連絡先 : yamagiko@asu.aasa.ac.jp

\section{稲上誠（いながみまこと）}

2010 年東京工業大学大学院総合理工学研究科人間環境システ 么専攻修了. 博士 (学術). 東京工業大学物理情報システム 専攻特任助教などを経て，2015年より名古屋大学未来社会創 造機構研究員. 専門領域: 環境心理学, 実験心理学ほ力. 日 本建築学会, 人間·環境学会, 日本生態心理学会, 各会員.

\section{田中貴紘（たなかたかひろ）}

2006年東京工業大学大学院総合理工学研究科修了. 博士（工 学). 東京農工大学大学院共生科学技術研究院助教などを経て, 2014年名古屋大学未来社会創造機構特任講師，2016年より同 大学特任准教授. 専門領域: HAI, HCIほか. 人工知能学会, 電子情報通信学会, ヒューマンインタフェース学会, 各会員.

\section{米川隆（よねかわたかし）}

1974年日本大学理工学部精密機械工学科卒業. 博士 (工学). トヨタ自動車(株)を経て，2014年より名古屋大学未来社会創造 機構研究員，2018年より同大学特任教授. 専門領域 : 自動車 の運動性能. 予防安全性能ほか. 自動車技術会, 日本機械学会, 各会員.

\section{河野直子（かわのなおこ）}

2006年名古屋大学大学院情報科学研究科単位取得退学. 博士 (学術). 名古屋大学大学院医学系研究科附属医学教育研究支 援センター特任助教, 同大学未来社会創造機構特任講師など を経て，2019年より大阪府立大学現代システム科学域環境シ ステム学類准教授. 専門領域：臨床心理学，高齢者心理学ほ か. 日本心理臨床学会, 日本心理学会, 日本老年精神医学会, 日本発達心理学会, 各会員.

\section{佐藤稔久（さとうとしひさ，正会員）}

2005年慶應義塾大学大学院理工学研究科修了. 博士 (工学). 産業技術総合研究所特別研究員などを経て，2015年より同研 究所自動車ヒューマンファクター研究センター行動モデリン グ研究チーム研究チーム長. 専門領域 : 運転行動の計測とモ デル化, 環境と行動のインタラクションなど. 日本人間工学会, 自動車技術会, 計測自動制御学会, 各会員. 
赤松幹之（あかまつもとゆき，正会員）

1984年慶応義塾大学大学院工学研究科管理工学専攻修了. 博 士 (工学). 工業技術院製品科学研究所などを経て，2014年 より産業技術総合研究所自動車ヒューマンファクター研究セ ンター首席研究員. 現在は同センター特命上席研究員. 専門 領域：人間行動の分析とモデル化, ヒューマンインタフェー スの設計と評価など. 日本人間工学会, モバイル学会, 自動 車技術会，各会員.
青木宏文（あおきひろふみ，正会員）

2002年東京工業大学大学院総合理工学研究科修了. 博士（工 学). 認定人間工学専門家. 東京工業大学研究員, MIT及び National Space Biomedical Research Institute研究員，トヨタ 自動車(株)東富士研究所, 名古屋大学大学院工学研究科特任准 教授を経て，2014年より名古屋大学未来社会創造機構特任教 授. 専門領域：人間工学，人間一機械系システム，有人宇宙 技術ほか. 日本人間工学会，IEEE，各会員，自動車技術会 理事. 